\title{
Peranan Sel Punca dalam Meregenerasi Jaringan Pulpa Gigi
}

\author{
Vinna Kurniawati Sugiaman ${ }^{1}$ \\ 1. Fakultas Kedokteran Gigi, Universitas Kristen Maranatha J1. Prof. Dr. Soeria \\ Soemantri, drg., MPH No. 64 bandung \\ Emal: vinnakurniawati@yahoo.co.id
}

\begin{abstract}
Abstrak
Injury pada pulpa gigi dapat menyebabkan terjadinya perubahan pada pulpa secara histopatologi, yang apabila terus berlanjut akan menyebabkan kerusakan pulpa menjadi irreversible sampai dengan kematian yang pada akhirnya perlu untuk dilakukan perawatan endodontik. Perawatan ini dapat mempertahankan gigi di rongga mulut dalam kondisi non vital, sehingga belakangan ini dikembangkan suatu teknologi baru yaitu teknologi tissue engineering dengan memanfaatkan sel punca, matriks, dan growth factor untuk meregenerasi jaringan yang mengalami kerusakan. Pada proses regenerasi, sel punca akan mengalami proliferasi dan diferensiasi menjadi berbagai macam sel yang terdapat pada jaringan pulpa, sehingga proses regenerasi jaringan pulpa yang mengalami kerusakan dapat terjadi dan pulpa dapat tetap dalam kondisi vital bertahan di rongga mulut.
\end{abstract}

Kata kunci: sel punca, regenerasi, jaringan pulpa, tissue engineering

\section{Pendahuluan}

Injury pada pulpa dapat terjadi karena penyebab mekanis berupa fraktur dan retakan, faktor kimia, infeksi mikroorganisme, dan faktor termal yang akan menimbulkan berbagai macam respon inflamasi termasuk perubahan vaskuler, limfatik, dan reaksi jaringan lokal yang pada akhirnya akan menyebabkan terjadinya berbagai macam komplikasi dan akan berpengaruh terhadap kualitas hidup gigi. ${ }^{1-3}$

Injury yang terjadi pada gigi dapat menyebabkan terjadinya perubahan pada pulpa gigi secara histopatologi dan akan menyebabkan timbulnya gejala klinis, sehingga perlu untuk dilakukan evaluasi terhadap status pulpa sebelum kerusakan pulpa menjadi irreversible yang pada akhirnya perlu untuk dilakukan perawatan endodontik. ${ }^{1,4,5}$

Belakangan ini keberhasilan perawatan endodontik mencapai 78-98\%, hal ini dapat dikatakan bahwa keberhasilannya relatif tinggi. Meskipun demikian, pada kondisi ini gigi akan menjadi non vital yang akan menyebabkan gigi menjadi lebih rapuh. Hal ini dapat terjadi karena setelah perawatan endodontik tidak ada lagi suplai darah dan inervasi pada gigi, serta gigi akan mengalami kehilangan kemampuan untuk membentuk dentin reparatif. Selain itu, prosedur perawatan endodontik juga akan meningkatkan kemungkinan terjadinya fraktur akar. $^{6,7}$ 
Oleh karena itu perlu dikembangkan suatu perawatan baru yang berdasarkan pada prinsip tissue engineering dengan penyediaan sel punca, matriks, dan regulator (growth factor) dalam meregenerasi jaringan pulpa agar gigi dapat bertahan di rongga mulut dalam keadaan vital. Perkembangan terapi ataupun perawatan yang akan datang, diharapkan dapat menggantikan jaringan yang mengalami kerusakan atau hilang dengan jaringan pulpa baru yang alami. Diharapkan kondisi ini dapat dicapai dengan mengaplikasikan konsep tissue engineering, sehingga dapat mewujudkan mimpi menjadi kenyataan. ${ }^{2,8,9}$

\section{Kajian Pustaka}

\section{Injury pada Pulpa Gigi}

Pulpa gigi merupakan jaringan yang unik dan kompleks yang menyediakan dukungan bagi dentin dengan menyediakan komponen utama penyusun gigi. Pulpa gigi merupakan jaringan yang responsibel terhadap pembentukan dentin dan merupakan jaringan ikat longgar yang terletak pada bagian tengah dari gigi, yang mana permukaan luarnya ditutupi dentin dan disusun dari sel, serat, substansi dasar yang mengandung glikosaminoglikans, pembuluh darah, dan syaraf. Pada bagian tengah dari pulpa disusun oleh vena yang besar, arteri, dan serabut syaraf yang dikelilingi oleh fibroblas dan serabut kolagen halus yang terdapat pada matriks interseluler. ${ }^{6,10-12}$

Kehilangan serabut syaraf sensoris akan menyebabkan kematian pulpa gigi yang tereksponasi secara cepat karena mengalami gangguan pada aliran darah. Aktivasi syaraf simpatis akan melepaskan neurotransmitter seperti nor epinefrin, adenosin trifosfat, dan neuropeptida Y (NPY) yang akan menyebabkan penurunan aliran darah pada pulpa. Sedangkan aktivasi syaraf parasimpatis akan melepaskan neurotransmitter seperti vasoaktif intestinal peptide (VIP). ${ }^{6,13}$

Pulpa gigi memiliki peranan yang penting sebagai berier untuk melawan bakteri, stimulus kimia, dan juga stimulus fisik. Ketika barier ini rusak karena injury traumatik ataupun karies, kompleks dentin pulpa memiliki kemampuan untuk memperbaiki diri dan berregenerasi. Penyembuhan pulpa sangatlah kompleks dan tergantung pada luasnya injury. Berbagai proses molekuler dan seluler terlibat pada proses penyembuhan ini yang bermanifestasi dengan terjadinya inflamasi dan perbaikan, baik pada level seluler ataupun level jaringan. Faktor penting yang terlibat dalam proses penyembuhan adalah adanya komponen vaskuler dan lingkungan mekanis. ${ }^{14-16}$

Jaringan pulpa sama dengan jaringan tubuh lainnya memiliki mekanisme pertahanan terhadap injury dengan menghilangkan infeksi. Penyembuhan luka merupakan suatu proses 
multifaktorial, termasuk migrasi, proliferasi, dan diferensiasi menjadi beberapa populasi sel dengan diikuti pembentukan matriks ekstra seluler. Pada kondisi terjadinya injury yang menyebabkan terbukanya pulpa yang dikaitkan dengan repon inflamasi, diikuti dengan tahapan terjadinya proses homeostasis dan pembentukan bekuan darah, respon inflamasi, proliferasi sel, dan juga remodeling jaringan. Namun, berbagai kondisi tersebut apabila tidak ditangani pada akhirnya akan menyebabkan terjadinya kematian pada pulpa gigi, sehingga perlu perawatan yang baik agar gigi dapat tetap bertahan di rongga mulut dalam keadaan yang vital. ${ }^{15-18}$

\section{Teknologi Tissue Engineering dalam Perawatan Endodontik}

Tantangan modern belakangan ini dibidang kedokteran gigi adalah mempertahankan pulpa gigi dalam keadaan vital, sehingga kehilangan gigi dapat dicegah. Pada kenyataannya, perawatan saluran akar biasanya akan mempertahankan gigi dengan menghasilkan devitalisasi gigi secara permanen. Teknologi Tissue Engineering dalam bidang endodontik dikenal dengan regenerative endodontic, yang merupakan suatu perkembangan yang baru dibidang endodontik. Menurut "The American Association of Endodontists", regenerative endodontic dapat didefinisikan sebagai prosedur yang dirancang berdasarkan prinsip biologi yang secara fisiologis memiliki tujuan untuk mengganti strukrur gigi yang mengalami kerusakan, termasuk dentin dan struktur akar, begitu juga sel-sel yang terdapat pada jaringan pulpa. ${ }^{18-21}$

Prosedur regenerative endodontic memiliki tujuan untuk meregenerasi kompleks dentin pulpa terutama jaringan pulpa, serta meregenerasi kerusakan pada koronal dentin (akibat pemaparan karies), dan meregenerasi akar gigi yang telah terresorbsi dengan tujuan mengembalikan struktur dan fungsi gigi secara fisiologis. Selain berfungsi dalam meregenerasi jaringan, teknologi ini juga bertujuan untuk mengganti, mempertahankan, dan meningkatkan fungsi jaringan. Prosedur ini bertujuan untuk membentuk dan mengirim jaringan baru untuk mengganti jaringan pulpa nekrotik dengan mengaplikasikan prinsip pengobatan regenerative dengan mengkombinasikan sel punca spesifik, matriks tiga dimensi, dan growth factor. ${ }^{20-22}$

\section{Sel Punca}

Sel punca meupakan sel yang memiliki kemampuan dalam self renewal, berproliferasi, berdiferensiasi, dan merangsang untuk membentuk berbagai macam sel.

Berdasarkan sumbernya, sel punca dapat diklasifikasikan menjadi: ${ }^{23-25}$ 
1) Autologus

2) Alogenik

3) Senogenik

4) Isogenik

Berdasarkan tahap perkembangannya dan asalnya, sel punca secara luas dapat diklasifikasikan menjadi:: $:^{25-27}$

1) Sel punca embri

Sel ini berasal dari embrio dan mampu untuk membelah, serta memperbaharui diri sendiri dalam jangka waktu yang lama.

2) Sel punca dewasa

Sel ini berasal dari jaringan postnatal, dapat diisolasi dari berbagai jaringan tubuh.

Sel punca adalah sel yang dikarakteristikkan oleh kemampuan yang tidak terbatas untuk berproliferasi dan berdiferensiasi menjadi tipe sel lain tergantung kepada kemampuan replikasinya. Sel punca dapat dibedakan menjadi: ${ }^{28-29}$

- Sel punca totipoten

- Sel punca pluripoten

- Sel punca multipoten

- Sel punca unipoten

- $\quad$ Induced Pluripotent Cell

Pemanfaatan sel punca dibidang kedokteran gigi biasanya diguankan dalam perwatan regenerative endodontic yang bertujuan untuk mengganti struktur gigi yang mengalami kerusakan.

\section{Sacffold/Matriks}

Matriks merupakan kerangka yang berperan dalam memfasilitasi sel punca dan growth factor untuk melekat, bermigrasi, serta berdiferensiasi. Matriks ini berbentuk polimer tiga dimensi untuk menyediakan lingkungan mikro yang secara biologi dan fisikokimia. Bermacam-macam matriks dapat didesain untuk regenerasi jaringan gigi dan bersifat biodegradable yang memberikan kemampuan bilogis. ${ }^{30,31}$

Matriks berperan dalam menyediakan support untuk proliferasi, organisasi sel, diferensiasi, dan juga vaskularisasi, sehingga dapat terjadi pertumbuhan sel. Tempat untuk perlekatan dan pertumbuhan sel dalam proses regenerasi ini disediakan oleh matriks dalam bentuk lingkungan tiga dimensi, yang dibuat dengan berbagai bentuk. Selain itu matriks juga berfungsi untuk mendorong terbentuknya respon biologis secara langsung dengan 
menyerupai struktur alami. Matriks dapat digunakan dalam berbagai bentuk (sperti: sponge, gel, ataupun serat) dan dapat dibuat dari berbagai biomaterial (seperti: polimer, keramik, dan metal) yang dapat bersifat biodegradable ataupun non biodegradable. ${ }^{7,13,18}$

\section{Growth Factor}

Growth factor merupakan protein yang berikatan dengan reseptor permukaan sel dan dapat menginduksi proliferasi dan diferensiasi sel, sehingga berperan penting dalam pertumbuhan, perkembangan, dan perbaikan jaringan, serta diperlukan untuk meningkatkan regenerasi jaringan, namun tergantung pada tipe jaringannya. Growth factor merupakan molekul peptida yang menghantarkan sinyal pada fungsi sel sebagai stimulator untuk terjadinya proliferasi dan diferensiasi sel. Aktivitas sel punca dapat dikontrol oleh growth factor meningkatan kecepatan proliferasi, menginduksi diferensiasi sel menjadi jaringan lain, menstimulasi terjadinya proses angiogenesis, atau menstimulasi sel punca untuk mensintesis dan mensekresikan matriks termineralisasi. ${ }^{32,33}$

\section{Diskusi}

Injury traumatik pada gigi permanen dapat menghasilkan trauma secara langsung ataupun tidak langsung yang dapat menghasilkan kerusakan pada struktur gigi dan periradikuler, yang dapat menyebabkan terjadinya injury pada pulpa gigi dengan atau tanpa kerusakan pada mahkota dan akar gigi. Kondisi-kondisi tersebut akan menghasilkan efek yang berbeda-beda terhadap pulpa. Respon pulpa akan dimulai untuk melakukan penyembuhan dan regenerasi. Repon pulpa tersebut bervariasi tergantung pada intensitas dan durasi injury. Secara umum efeknya berupa inflamasi akut, inflamasi kronis, dan nekrosis pulpa. ${ }^{6,14,34}$

Terapi injury pada pulpa yaitu perawatan endodontik adalah perawatan saluran akar yang bertujuan untuk menghilangkan kontaminan, mengisi ulang saluran akar, dan menutupnya dengan bahan sintetis. Keberhasilan perawatan teknik ini pada beberapa decade belakangan, dapat mempertahankan fungsi gigi untuk waktu yang cukup lama dengan jaringan pulpa non vital. Oleh karena itu perlu dikembangkan suatu teknik perawatan yang dapat mempertahankan jaringan pulpa gigi yang mengalami kematian dalam keadaan vital, yaitu dengan memanfaatkan teknologi tissue engineering. Prosedur ini bertujuan untuk membentuk jaringan baru untuk mengganti jaringan pulpa nekrotik dengan mengaplikasikan prinsip pengobatan regenerative dengan mengkombinasikan sel punca spesifik, scaffold tiga dimensi, dan growth factor untuk meregenerasi kompleks dentin pulpa dan merevitalisasi gigi. ${ }^{20,35}$ 
Pada pemanfaatan teknologi ini, Sel punca mesenkimal memiliki kemampuan untuk bermigrasi menuju daerah yang mengalami injury dan berdiferensiasi menjadi tipe sel tertentu. Proses proliferasi dan diferensiasi sel punca biasanya diinduksi oleh growth factor, sehingga berperan penting dalam pertumbuhan, perkembangan, dan perbaikan jaringan, serta diperlukan untuk meningkatkan regenerasi jaringan. Growth factor akan meningkatan kecepatan proliferasi, menginduksi diferensiasi sel menjadi jaringan lain, menstimulasi terjadinya proses angiogenesis, atau menstimulasi sel punca untuk mensintesis dan mensekresikan matriks termineralisasi. ${ }^{30,32,33,36}$

Proses regenerasi ini diawali dengan terjadinya adhesi, proliferasi, migrasi, dan diferensiasi sel punca mesenkimal menjadi sel odontoblas dan fibroblas serta terekspresinya growth factor yang terjadi pada daerah yang mengalami kerusakan dengan barier matrik. Pada tahap biomolekuler proses ini ditandai dengan perkembangan sel, termasuk proses pensinyalan yang kompleks untuk membentuk berbagai macam molekul pensinyalan yang akan mempengaruhi reseptor pada permukaan sel dan juga sistem transkripsi. Hal ini dapat terjadi karena sel punca memiliki kemampuan untuk berdiferensiasi menjadi sel endotel yang dapat menyebabkan terjadinya pembentukan pembuluh darah baru, serta terjadi peningkatan kepadatan pembuluh darah baru dan regenerasi pada jaringan syaraf. Karena kemampuan tersebut maka regenerasi jaringan pulpa gigi dapat terjadi ${ }^{37,38}$

\section{Simpulan}

Sel punca memiliki peranan penting dalam meregenerasi jaringan pulpa gigi yang mengalami kerusakan melalui aplikasi teknologi tissue engineering melalui kemampuannya untuk berproliferasi dan berdiferensiasi menjadi berbagai macam sel yang terdapat pada jaringan pulpa gigi.

\section{Daftar Pustaka}

1. Pinkham JR, Paul SC, Henry WF, Dennis JM, \& Arthur N. Pediatric Dentistry Infancy Through Adolesence. $4^{\text {th }}$ ed. St. Louis: Saunders; 2005.

2. Demarco. F. F, Marcus. C. M. C, Bruno. N. C, Luciano. C, Vivien. T. S, \& Jacques. E. N. Dental Pulp Tissue Engineering. Braz Dent J. [serial online] 2011 [cited 24 Mei 2013]; 22(1): 3-14. Available from: URL: http://www.ncbi.nlm.nih.gov/pubmed/21519641

3. Anilkumar. K \& Geetha. A. "Tissue Engineering”-Future Concepts in Endodontics-A Short Review. Journal of Clinical and Diagnostic Research. [serial online] 2010 [cited 24 Mei 2013]; 4: 3282-3286. Available from: URL: http://www.jcdr.net/articles/PDF/949/1148+E_C_F(J)_R(J)_PF_p.pdf

4. Schuurs. A. Pathology of the Hard Dental Tissues. USA: Wiley Blackwell; 2013: 210234. 
5. Qualtrough AJE, Julian S, Leean M, \& Paul B. Principles of Operative Dentistry. USA: Wiley Blackwell; 2005.

6. Sharma S \& Neelam M. A Comparative Evaluation of Natural and Artificial Scaffold in Regenerative Endodontics: A Clinical Study. Saudi Endodontic Journal. [serial online] 2016 [cited 15 Februari 2016]; 6 (1): 9-15. Available from URL: http://www.saudiendodj.com/downloadpdf.asp?issn=1658-

5984; year $=2016$; volume $=6 ;$ issue $=1 ;$ spage $=9 ;$ epage $=15 ;$ aulast $=$ Sharma; type $=2$

7. Huang. T. J. G. Pulp and Dentin Tissue Engineering and Regeneration: Current Progress. Regen Med. [serial online] 2009 [cited 24 Mei 2013]; 4(5): 1-18. Available from: URL: progress.:http://www.ncbi.nlm.nih.gov/pmc/articles/PMC2785543/pdf/nihms155244.pdf

8. Bansal. M \& Rajesh. B. Regenerative Endodontics: A State of the Art. Indian Journal of Dental Research. [serial online] 2011 [cited 24 Mei 2013]; 22(1): 122-131. Available from: http://imsear.hellis.org/bitstream/123456789/139964/1/ijdr2011v22n1p122.pdf

9. Haniastuti. T, Phides. N, \& Ariadna. A. D. The Role of Transforming Growth Factor beta in Tertiary Dentinogenesis. Dent. J. [serial online] 2008 [cited 24 Mei 2013]; 41(1): 1520. Available from: URL: http://journal.unair.ac.id/filerPDF/DENTJ-41-1-04.pdf

10. Balogh MB \& Margareth JF. Illustrated Dental Embryology, Histology, and Anatomy. $2^{\text {nd }}$ ed. St. Louis, Missouri : Elsevier; 2006: 179-205.

11. Avery. J. K \& Daniel. J. C. Essentials of Oral Histology and Embryology: A Clinical Approach. $3^{\text {rd }}$ ed. St. Louis, Missouri : Elsevier; 2007: 121-144.

12. Berkovitz. B. K. B, G. R. Holland, \& B. J. Moxham. Oral Anatomy, Embryology and Histology. $3^{\text {rd }}$ ed. St. Louis, Missouri : Elsevier; 2006:149-167, 332-334.

13. Huang. G. T. J. Dental Pulp and Dentin Tissue Engineering and Regeneration: Advancement and Challenge. Frontiers in Bioscience. [serial online] 2011 [cited 13 September 2013]: 788-800. Available from: URL: http://www.endoexperience.com/documents/Dentalpulpanddentintissueengineeringandreg eneration-advancementandchallengeHuang2011.pdf

14. Simon SRJ, Berdal A, Cooper PR, Lumley PJ, Tomson PL, \& Smith AJ. Dentin Pulp Complex Regeneration: from Lab to Clinic. Adv dent Res. [serial online] 2011 [cited 25 September 2013 ]; 23 (3): 340-345. Available from: URL:http://www.endoexperience.com/documents/DentinPulpComplexRegenerationfromLabtoClinic2011.pdf.

15. Zheng L, Kazuharu A, Koichiro I, Masataka I, Kiyomi I, Takeshi I, et all. Matrix Metalloproteinase-3 Accelerates Wound Healing Following Dental Pulp Injury. The American Journal of Pathology. [serial online] 2009 [cited 25 September 2013 ]; 175 (5): 1905-1914. Available from: URL: http://www.ncbi.nlm.nih.gov/pmc/articles/PMC2774055/pdf/JPATH175001905.pdf

16. Cooper PR, Michelle JH, \& Anthony JS. Inflamation and Regeneration in the Dentin Pulp Complex: A Double-edge Sword. Journal of Endodontic. [serial online] 2014 [cited 15 Desember 2014 ]; 40 (4s): s46-s51. Available from: URL: http://www.jendodon.com/article/S0099-2399\%2814\%2900082-X/pdf

17. Larjava. H. Oral Wound Healing: Cell Biology and Clinical Management. USA: Wiley Blackwell; 2012: 313-332.

18. Sangappa SK, Nagarathna J, A Pravin K, \& Shruti. Regenerative Endodontic: Current Progress. IOSR Journal of Dental and Medical Sciences. [serial online] 2014 [cited 15 Desember 2014]; 13 (4): 88-95. Available from URL: http://www.iosrjournals.org/iosrjdms/papers/Vol13-issue4/Version-4/Q013448895.pdf

19. Kitamura C, Tatsuji N, Masamichi T, Yasuhiko T, Eijiro J, Ayako W, et all. Regeneration Approaches for Dental Pulp and Periapical Tissues with Growth Factor, Biomaterials, 
and Laser Irradiation. Journal Polimers. [serial online] 2011 [cited 25 September 2013 ]; 3: 1776-1793. Available from: URL: http://www.mdpi.com/journal/polimers.

20. Kumar P and Shantha M. Regenerative Endodontics: An Update. Journal of International Academic Research for Multidiciplinary. [serial online] 2014 [cited 15 Desember 2014]; 2 (4): 650-658. Available from URL: http://www.jiarm.com/MAY2014/paper13872.pdf

21. Jamal M, Sami C, Harold G, \& Sherif MK. Dental Stem Cell and Their Potential Role in Regenerative Medicine. Journal of Medical Sciences. [serial online] 2011 [cited 18 Desember 2014]; 4 (2): 53-61. Available from URL: http://www.benthamopen.com/jms/articles/V004/S20053JMS/53JMS.pdf

22. Schmalz G \& Anthony JS. Pilp Development, Repair, and Regeneration: Challenges of the Transition from Traditional dentistry to Biuologically Based Therapies. Journal of Endodontic. [serial online] 2014 [cited 15 Desember 2014]; 40 (4s): s2-s5. Available from URL: http://www.jendodon.com/article/S0099-2399\%2814\%2900079-X/pdf

23. Marawar PP, Mani A, Sachdev S, Sodhi NK, \& anju A. Stem Cell in Dentistry: An Overview. Pravara Med Rev. [serial online] 2012 [cited 05 November 2013 ]; 4 (2): 11-15. Available from: URL: http://www.pravara.com/pmr/pmr-4-2-4.pdf

24. Chandki R, M Kala, Priyank B, \& Ruchi B. From Stem to Roots: Tissue Engineering in Endodontics. J Clin Exp Dent. [serial online] 2012 [cited 15 Desember 2014]; 4(1): 66-71. Available from:

URL: http://www.medicinaoral.com/odo/volumenes/v4i1/jcedv4i1p66.pdf

25. Mouli PEC, S Manoj K, B Senthil, S Parthiban, R Priya, \& R Subha. Stem Cell in Dentistry: A Review. J Pharm Sci \& Res. [serial online] 2012 [cited 05 November 2013 ]; 4 (7): 1872-1876. Available from: URL: http://www.pharmainfo.in/jpsr/Documents/Volumes/vol4issue07/jpsr\%2004120706.pdf

26. Yarak. S \& Oswaldo. K. O. Human Adipose Derived Stem Cell: Current Challenges and Clinical Perspective. An Bras Dermatol. [serial online] 2010 [cited 17 September 2013]; 85(5): 647-656. Available from: URL: http://www.scielo.br/pdf/abd/v85n5/en_v85n05a08.pdf

27. Zuk. P. A. The Adipose-derived Stem Cell: Looking Back and Looking Ahead. Molecular Biology of the Cell. [serial online] 2010 [cited 17 September 2013]; 21: 1783-1787. Available from: URL: http://www.molbiolcell.org/content/21/11/1783.full.pdf

28. Peng. L, Ling. Y, \& Xue. D. Z. Mesenchymal Stem Cell and Tooth Engineering.International Journal of Oral Science. [serial online] 2009 [cited 17 September 2013]; 1(1): 6-12. Available from: URL: http://www.prgmea.com/docs/tooth/96.pdf

29. Gimble JM, Adam JK, \& Bruce AB. Adipose Derived Stem Cell for Regenerative Medicine. Journal of The American Hearth Association. [serial online] 2007 [cited 25 September 2013 ]; 100: 1249-1260. Available from: URL: http://circres.ahajournals.org/content/100/9/1249.full.pdf+html

30. Murray. P. E, Franklin. G, \& Kenneth. M. H. Regenerative Endodontics: A Review of Current Status and a Call for Action. JOE. [serial online] 2007 [cited 13 September 2013]; 33(4): 377-390. Available from: URL: http://www.ncbi.nlm.nih.gov/pubmed/17368324

31. Nakashima M \& Akifumi A. The Applcation of Tissue Engineering to Regeneration of Pulp and Dentin in Endodontics. Journal Of Endodontic. [serial online] 2005 [cited 22 September 2013 ]; 31 (10): 711-718. Available from: URL: http://www.endotreatment.gr/media/files/REGENERATIVE-ENDODONTICS/PIIS$\underline{\text { 6.pdf }}$

32. Saber SE. Tissue Engineering in Endodontics. Journal of Oral Science. [serial online] 2009 [cited 13 September 2013]; 51(4): 495-507. Available from URL: 
http://files.cultivoscelulares.webnode.es/200000132-

1dd901ed30/Tissue\%20engineering\%20in\%20endodontics.pdf

33. Lynch. S. E, Robert. J. G, \& Robert. E. M. Tissue Engineering: Application in Maxilofacial Surgery and Periodontics. China: Quintessence Publishing Co, Inc; 1999: 313, 185-200.

34. Yu. C \& P. V. Abbott. An Overview of the Dental Pulp: its Functions and Responses to Injury. Australian Dental Journal Supplement. [serial online] 2007 [cited 05 September 2013]; 52(1): 4-16. Available from: URL: http://www.ada.org.au/app_cmslib/media/lib/0704/m70470_v1_633112728503963750.pd $\underline{f}$

35. Zhang W \& Pamela CY. Vital Pulp Therapy-Current Progress of Dental Pulp Regeneration and Revascularization. International Journal of Dentistry. [serial online] 2010 [cited 14 November 2013]; 10: 1-9. Available from URL: http://www.ncbi.nlm.nih.gov/pmc/articles/PMC2861196/pdf/IJD2010-856087.pdf

36. Gandhi. A, Taru. G, \& Natasha. M. Dental Pulp Stem Cell in Endodontic Research: A Promising Tool for Tooth Tissue Engineering. RSBO. [serial online] 2011 [cited 13 September 2013]; 8(3): 335-340. Available from: URL: http://vdisk.univille.edu.br/community/depto_odontologia/get/ODONTOLOGIA/RSBO/ RSBO_v8_n3 julho-setembro2011/RSBO-v8n3-artigo14.pdf

37. Wang JS, Peng C, \& Kai T. The Application Prospects of Adipose-Derived Stem Cell in Periodontal Tissue Reconstruction. E-Journal of Dentistry. [serial online] 2013 [cited 17 September 2013]; 3 (1): 292-301. Available from URL: http://www.ejournalofdentistry.com/articles/e-JOD7BD5F6F930-02FB-4209-8A03D82012.pdf

38. Lindroos B, Riitta S, \& Susanna M. The Potential of Adipose Stem Cells in Regenerative Medicine. Stem Cell Rev and Rep. Humana Press. [serial online] 2010 [cited 05 November 2013]: 1-12. Available from URL: http://www.stemcellmd.org/wpcontent/uploads/2011/10/Adipose-Stem-Cells.pdf 